\title{
The need for occupational health services in Bloemfontein
}

\author{
P P du Rand, PhD, Program Director, School of Nursing, Faculty of Health Sciences, UFS \\ W Schoeman, MSocSc, School of Nursing, Faculty of Health Sciences, UFS
}

\section{Opsomming}

Die navorsing is onderneem om die behoefte aan beroepsgesondheidsdienste in Bloemfontein te bepaal vir moontlike aksies om beroepsgesondheidsdienste in klein en medium bedrywe te beplan. In die probleemstelling is gemeld dat klein en medium bedrywe nie algemeen oor die dienste van ' $n$ beroepsgesondheidsverpleegkundige beskik nie. Die opname metode is gebruik en die navorsing was beskrywend van aard. Vraelyste is gebruik om inligting te versamel en die navorser het met behulp van ' $n$ kontrolelys die omgewing vir veiligheidsrisiko's geëvalueer. Drie steekproewe is uitgevoer naamlik 'n ewekansige steekproef om die bedrywe en werknemers te identifiseer en doelgerigte seleksie om die bestuurders te identifiseer. Hoofbevindinge van die navorsing het uitgewys dat bestuurders en werknemers nie oor kennis van beroepsgesondheid beskik nie.

Bestuurders was ook nie op hoogte van die moontlike beroepsgevare in hul bedrywe nie, maar hulle het egter positief reageer en behoefte aan dienste uitgespreek. Werknemers was in ' $n$ mate bewus van beroepsgevare en het ook ' $\mathrm{n}$ behoefte aan dienste geopenbaar. Die hoofrede van die afwesigheid van dienste is die bekostigbaarheid daarvan. Een van die aanbevelings is dat die beroepsgesondheids-verpleegkundiges ' $n$ groot taak het om die nodige inligting aan werkgewers en werknemers te verskaf. Beroepsgesondheid verpleegkundiges kom voor groot uitdagings te staan.

\section{Summary}

The research was undertaken to ascertain the need for occupational health services in Bloemfontein with the possibility of planning such services in small and medium industries. As mentioned in the problem statement, small and medium industries generally do not employ an occupational health nurse. The survey method was used and the research was descriptive in nature. Questionnaires were used to collect information and the researcher evaluated the environment for safety hazards by means of a checklist. Three samples were conducted: a samples test to identify the industries and employees and goal-directed selection to identify the managers. The main findings of the research showed that managers and employees do not know about industrial health.

Managers were unaware of the occupational hazards in their industries but they responded positively and expressed the need for services. The workers were aware of occupational hazards to a certain extent and also expressed the need for services. The main reason for the absence of services is their unaffordabilitiy. Some of the recommendations are that industrial health nurses have an important task in providing appropriate information to employers and employees. Occupational nurses face great challenges.

\section{Introduction}

The importance of occupational health services is not in dispute, yet there are still certain industries that do not provide their workers with these services (Schoeman, 1999:1). There may be a number of reasons for this situation, for instance the poor economic climate, the policy of a particular industry or legislation that cannot be enforced. There is, however, awareness among the community and the workers in industry that they have a right not to be affected adversely by the work place. This view was stated by the World Health Organization as early as 1950 (Labuschagne, 2001:2). An investigation was therefore undertaken in Bloemfontein to determine the need for occupational health services in industries in order to make appropriate recommendations for the implementation of such services in smaller and medium industries.

\section{Problem statement}

Bloemfontein is not a large industrial city. Only five of the 200 businesses in Bloemfontein have occupational health nurses in their service and only three of these are in full-time employment. The others have mornings - only posts or are paid by the hour. According to the National Occupational Safety Association (NOSA) those businesses that have industrial health nurses in their service have more than 200 employees on their establishment. Smaller and medium industries therefore do not, as a rule, have occupational health nurses on their staff (Schoeman, 1999:1). The question is, how are the health and safety of these workers ensured?

According to the literature there is a lack of occupational health services in medium and small industries in other countries too. Jeyaratnam (1992:81) states that only $40 \%$ of industries with 
fewer than 100 workers in Indonesia have occupational health services and in the Phillipines occupational health services in smaller industries are delivered by first-aid workers.

The guidance by the Health and Safety Executive on Successful Health and Safety Management makes it quite clear that the responsibility for health and safety must begin with top management. Examples of health and safety philosophies as quoted by the HSE (1997) include the following

"Health and safety is a management responsibility of equal importance to production and quality; and

We believe nothing is more important than safety ... not production, not sales, not profits." (Health and Safety Executive 1997:58)

Health and safety legislation in South Africa is clear as regards requirements of the employer, i.e. to ensure that safe and healthy conditions for workers are maintained (Schoeman 1999:4). Yet many safety surveys still show a wide gap in the perceptions of safety between managers (who would never hesitate to approve production being stopped because of a safety problem), front-line workers (who feel that production pressure has a serious effect on safety) and especially first-line supervisors (who know that production takes preference over safety). However, Budworh (1997:20) in his research found on one site that senior members of staff were convinced that safety was being managed well and that staff were well trained, well informed and not taking short cuts. In contrast junior staff felt poorly trained, that the responsibilities were not well defined and that safety was not being taken seriously.

It is clear from the above that top management and lower level workers have many misconceptions about safety and health. An investigation appeared to be necessary in medium and small businesses to ascertain the real needs regarding occupational health services in Bloemfontein.

\section{Definitions of terms}

For requirements of this research the following definitions were used.

- Smaller industry: An industry with 50 to 99 employ -ees.

- Medium industry: An industry with 100 to $150 \mathrm{em}$ -ployees.

- Large industry: An industry with more than $150 \mathrm{em}$ -ployees.

- Occupational health: This includes the promotion and maintenance of the physical, psychological and so cial welfare of all employees. It implies industrial hy -giene, biological monitoring of the environment, the management of minor ailments and the presentation of health education (Occupational Health and Safety Act, Act 85 of 1993).

\section{Objectlves}

The objectives were to:

- $\quad$ identify the need for occupational health services by the management of industries

- determine the awareness the management of indus -tries of the occurrence of occupational diseases and occupational injuries in their particular industries

- $\quad$ identify the needs expressed by employees for occupa -tional health services

- determine reasons why occupational health services have not been introduced in some industries.

\section{Research design and method}

A non-experimental design was used as no variables were manipulated (Uys \& Basson, 1991:48; Wilson, 1989:145). The survey method by means of a structured questionnaire was followed and the research objective was descriptive and explorative. The research was contextually bound to the context of the need for occupational health services of employers and employees in Bloemfontein.

\section{Research techniques}

A variety of research techniques was used to collect data.

\section{Review of the literature}

A computer search of South African as well as international sources were conducted. In view of the fact that occupational health gained momentum only in the early seventies when occupational health courses were introduced, sources of the seventies and later were used. Very little information in South Africa is available about a private occupational health service as this is a new and unknown field for employers and private nurses.

\section{Questioning}

The need for occupational health services in Bloemfontein was ascertained by means of questionnaires completed by employers and employees.

\section{Observation}

The researcher explored the environment and nature of each industry to check the answers of the respondents with regard to occupational hazards as identified. In this way the researcher was able to determine whether the respondents were aware of the occupational hazards in their particular industry. The observations were done with the aid of a checklist. 


\section{Data gathering instruments Questionnaires completed by employers and employees}

The questionnaires were compiled by the researcher with the aim of ascertaining the needs of the employers and the employees for occupational health services. The questionnaires were preceded by a letter in which the aim of the questionnaire and an explanation of how to complete it were set out. Two data collection instruments were compiled, one for employers and one for employees.

\section{Validity and reliability of the questionnaires Validity}

Validity may be defined as the degree to which an instrument tests what it is intended to test. Content and face validity were used. Content validity determines whether all the main aspects of the study have been included (Burns \& Grove, 1993:346). This information was obtained from the literature, representatives of occupational health nurses and research.

The researcher therefore attempted to include sufficient questions to achieve the objectives. The questionnaires were submitted to domain experts, i.e. three experts on occupational health: a research expert, an occupational health nurse and a private occupational health medical practitioner.

The brief of the experts was to determine in terms of the broad research objective whether:

- $\quad$ the questions were representative of the domain speci -fied in the objectives (Wilson, 1989:357);

- $\quad$ the objectives were satisfactorily built into the ques -tions; and

- the appearance of the questionnaires showed face va -lidity.

Corrections were made in terms of the findings of the domain experts and the questionnaires were tested in the pilot study.

The following corrections were made:

- the number of inspections carried out by the Depart -ment of Manpower was added as the occupational health nurse found this to be a weakness in occupa -tional health services;

- the required responses were divided into subsections; and

- the job satisfaction of workers was added.

Content validity was obtained as follows: The objectives were covered by specific questions. The researcher collected information about the specific needs of the workers regarding occupational health services, specific needs of the employers and reasons why occupational health services had not been implemented. These questions were submitted to a panel of experts in occupational health, research, a private occupational health nurse and doctor to determine the content validity.
Accuracy is part of validity because if the instrument is accurate the information that should be obtained will be obtained (Burns \& Grove, 1993:347; Polit \& Hungler 1983:394). The researcher compiled the data collection instrument in collaboration with the domain experts.

\section{Reliability}

Reliability is the most important prerequisite for any data collection instrument (Uys \& Basson, 1991:82). The reliability of an instrument can be ascertained by the degree to which it provides the same information every time it is used (Burns \& Grove, 1993:291).

In this study reliability was measured by the test-retest method. The instruments were applied in a representative sample of the target population in a pilot study. The respondents were requested to complete the questionnaire again after a fortnight. According to Wilson (1989:306) there is no set standard for the interval of time between two tests, but it must be long enough to ensure that respondents are not able to recall their responses to the first test. After this the two sets of questionnaires were compared to determine reliability. The respondents gave the same responses.

Mouton and Marais (1989:79) state that the reliability of observations or data can be determined by the following variables:

- the researcher;

- the measuring instrument; and

- the research context, that is, the circumstances under which the research takes place. Political activities such as trade union activity in a specific industry may have an influence and especially the extent to which the trade unions dictate to and make demands on the em -ployers and workers.

The researcher distributed the questionnaires personally and explained to the workers where necessary. The questionnaires of illiterate workers would have been filled in for them after the questions were read out to them. This would have ensured reliability as the technique remained the same. The same procedure would have been followed in the pilot study. However, as it happened, no illiterate workers were drawn for the study so no questions were asked orally. The questionnaires were translated into Sotho.

No reliability coefficient was statistically determined as consistency was assumed as a result of the judgment of the domain experts.

\section{Pilot study}

A pilot study was conducted in non-selected industries to:

- test the validity and reliability of the questionnaires;

- test the feasibility of the study;

- trace problems in the research design;

- determine the accuracy of the data collection instru -ment;

- familiarise the researcher with the data collection in strument; and 
provide the researcher with experience of the subject, methodology and set-up of the businesses and re -spondents (Burns \& Grove, 1993:48)

A pilot study was conducted in ten per cent of the industries. Three industries were used and ten per cent of the workers of each industry completed the questionnaires. The businesses used for the pilot study were not included in the sample. The respond ents gave the same responses in the test-retest to all the questions and all the respondents completed the questionnaires.

During the pilot study the researcher realised that the original method of handing out questionnaires which the respondents were required to fill in immediately could not be realised. The reason was that due to pressure of work the employers would not excuse the workers for long enough to fill in the questionnaires. To ensure good relationships with the employers the researcher distributed the questionnaires, explained what was required to the workers and collected them the following day.

\section{Observation of the working environment}

According to Mouton and Marais (1989:160) observation in science can take many forms, such as recording the activities in the environment in terms of specific criteria. The researcher observed the working environment of the various industries to ascertain whether the employers and employees were aware of the particular occupational hazards in their working environment.

In view of the fact that the researcher had to remain objective at all times, the observations were conducted in terms of a

\section{Validity and reliability of the instrument to identify occupational hazards \\ - Validity}

The five-star system of NOSA was adapted and used to compile the instrument for observation of the environment. This system was used as it is approved and used by NOSA to inspect industries.

Content validity was ensured by virtue of the fact that the instrument was checked by an official of NOSA for completeness. The researcher did not use all aspects of the 5 star system as it is an extensive programme for large mines and factories. Only aspects that applied to the industries in the research were used which is why the official was asked to check it. The instrument was accurate as regards the industries in the study as the information obtained was intended to be obtained.

\section{- Reliability}

Reliability of the instrument resided in the fact that it was an approved instrument of NOSA and that it provided the same information every time even though it was used by different evaluators (Burns \& Grove, 1993:291).

Mouton \& Marais (1989:79) state that the reliability of observations or data is also determined by variables such as the researcher, the measuring instrument and the research context. The researcher inspected the working environments personally with the same measuring instrument and the circumstances remained the same. The researcher did not manipulate the environments and recorded only that which was observed.

\section{Table 1: Sample framework of industries in Bloemfontein registered with the Chamber of Commerce and Industry ( $N=52)$}

\begin{tabular}{|l|c|c|}
\hline \multicolumn{1}{|c|}{ INDUSTRIES } & NUMBER & 30\% SAMPLE \\
\hline Small industries & 38 & 11 \\
\hline Medium industries & 14 & 4 \\
\hline
\end{tabular}

structured, objective, standardised observation technique (Mouton \& Marais, 1989:165). A checklist was used as a guide.

The five star NOSA system was adapted by the researcher. It includes aspects with regard to the environment for example the floors, illumination, ventilation, facilities, and pollution. Aspects with regard to safety measurements were also included. The researcher asked the manager or personnel officer to show her the working environment to enable her to check her answers regarding occupation health hazards with those of the employers and employees. The visits to the industries took an average of one hour per industry and the managers were all very helpful.

\section{Sample}

Three samples were used:

- $\quad$ one for the industries;

- $\quad$ one for the employers; and

- $\quad$ one for the workers.

\section{- Sampling of the industries}

A stratified random sample (Uys \& Basson, 1991:99) of all the industries registered with the Chamber of Commerce and Industry in Bloemfontein was drawn. The aspect used for stratification was the size of the industry. A stratification of medium (100-150 work 
-ers) and small (50-99 workers) was carried out. The sample comprised $30 \%$ of the population.

Random selection of $30 \%$ of the industries in each group of small and medium industries was carried out. The names of the small industries were listed alpha -betically and every fourth industry was selected. The same method was followed with the medium indus -tries and in this case every third name was selected as fewer medium industries were listed (See Table 1). A random stratified selection of the 52 industries reg -istered with the Chamber of Commerce and Industry in Bloemfontein was done. These industries have 50 workers and not more than 150 workers. Thirty per -cent of the businesses and $10 \%$ of the total number of workers in each business were selected. There were 38 small and 14 medium industries in Bloemfontein that met the inclusion criteria.

The following information was obtained before the sample was drawn:

industries registered with the Chamber of Commerce and Industry; and number of workers.

The information was obtained from the Chamber of Commerce and Industry in Bloemfontein who conducted a computer search.

\section{- Obtaining consent}

The research was planned in collaboration with the Bloemfontein National Occupational Safety Associa -tion (NOSA) and the Bloemfontein Chamber of Com -merce and Industry as the industries are registered with them

After the sample was drawn the industries concerned were contacted by telephone and appointments were made with the managers. Their consent for the re -search was obtained and no problems were encoun -tered in this regard. The appointments were con firmed in writing.

\section{- $\quad$ Sampling of workers}

A random sample of $10 \%$ of the workers in each in -dustry was obtained. The percentage was determined by a statistician of the University of the Free State as it appeared that this was adequate to generalise in terms of Bloemfontein. The sampling is illustrated in Table 2

This table shows that the eleven small industries com -prised retail, printing, security, industrial, hotel, fur

\section{Table 2: Sample determination of the employees in each industry ( $N=15)$}

\begin{tabular}{|l|c|c|}
\hline \multicolumn{1}{|c|}{ TYPE OF INDUSTRY } & NUMBER OF EMPLOYEES & 10\% SAMPLE \\
\hline Financing industry & 50 & $\mathbf{1 0}$ \\
\hline Motor industry & 100 & 5 \\
\hline Training centre & 50 & 10 \\
\hline Retail industry no. 1 & 100 & 5 \\
\hline Retail industry no. 2 & 50 & 5 \\
\hline Printing industry & 50 & 5 \\
\hline Security industry & 50 & 6 \\
\hline Industry no. 1 & 60 & 5 \\
\hline Industry no. 2 & 50 & 12 \\
\hline Food industry no. 1 & 120 & 10 \\
\hline Food industry no. 2 & 103 & 5 \\
\hline Hotel industry no. 1 & 50 & 7 \\
\hline Hotel industry no. 2 & 70 & 4 \\
\hline Furniture industry & 47 & 5 \\
\hline Hairdressing industry & 50 & \\
\hline
\end{tabular}


-niture and hairdressing businesses and a training centre.

The four medium industries with 100 to 150 workers comprised a motor, retail and two food industries.

\section{Sampling employers}

A non-random sample of the employers was drawn. Goal-directed selection was carried out in terms of in -clusion criteria. These were that the person should be in a management post. According to Uys and Basson (1991:101) goal-directed selection is also about the convenience of the researcher. Anyone in a management position who was willing and available was considered to be adequate to provide the required information.

\section{Table 3: Managers' knowledge of occupational hazards in the industries $(N=14)$ (to be continued)}

\begin{tabular}{|c|c|c|}
\hline TYPE OF INDUSTRY & $\begin{array}{l}\text { Occupational hazards } \\
\text { identified by researcher }\end{array}$ & $\begin{array}{l}\text { Occupational hazards } \\
\text { identified by managers }\end{array}$ \\
\hline Furniture industry & $\begin{array}{ll}\text { - } & \text { Defective machinery } \\
\text { - } & \text { Noise } \\
\text { - } & \text { Dust } \\
\text { - } & \text { Eye injuries } \\
\text { - } & \text { Inadequate industrial } \\
& \text { housekeeping } \\
\text { - } & \text { Robberies }\end{array}$ & - Defective machinery \\
\hline Food industry No. 1 & $\begin{array}{ll}- & \text { Slippery floors } \\
\text { - } & \text { Inadequate protective } \\
& \text { clothing } \\
\text { - } & \text { Faulty machinery } \\
\text { - } & \text { Fire hazard (stoves) } \\
\text { - } & \text { Back injuries } \\
- & \text { Defective electrical } \\
& \text { appliances/wiring } \\
- & \text { Exposure to heat and cold } \\
- & \text { motor accidents } \\
- & \text { Robbery/violence } \\
\end{array}$ & - None mentioned \\
\hline Food industry No. 2 & $\begin{array}{ll}\text { - } & \text { Defective machinery } \\
\text { - } & \text { Dust } \\
\text { - } & \text { Flour dust } \\
\text { - } & \text { Noise } \\
\text { - } & \text { Back injuries } \\
\text { - } & \text { Motor accidents } \\
\text { - } & \text { Violence/robbery } \\
\text { - } & \text { Burns (ovens) } \\
\text { - } & \text { Inadequate protective } \\
& \text { clothing }\end{array}$ & - Defective machinery \\
\hline Hotel industry No. 1 & $\begin{array}{ll}\text { - } & \text { Back injuries } \\
\text { - } & \text { Violence } \\
\text { - } & \text { Slippery floors } \\
\text { - } & \text { Burns (stoves) } \\
\text { - } & \text { Eye injuries } \\
\text { - } & \text { Electrical appliances/wiring } \\
\text { - } & \text { Motor accidents } \\
\end{array}$ & - None mentioned \\
\hline Hotel industry No. 2 & $\begin{array}{ll}\text { - } & \text { Back injuries } \\
\text { - } & \text { Violence } \\
\text { - } & \text { Slippery floors } \\
\text { - } & \text { Burns (stoves) } \\
\text { - } & \text { Eye injuries } \\
\text { - } & \text { Electrical appliances/wiring } \\
\text { - } & \text { Motor accidents }\end{array}$ & - Inadequate security \\
\hline
\end{tabular}




\begin{tabular}{|c|c|c|}
\hline TYPE OF INDUSTRY & $\begin{array}{l}\text { Occupational hazards } \\
\text { identified by researcher }\end{array}$ & $\begin{array}{l}\text { Occupational hazards } \\
\text { identified by managers }\end{array}$ \\
\hline Printing industry & $\begin{array}{ll}\text { - } & \text { Injuries caused by } \\
& \text { machinery } \\
\text { - } & \text { Noise } \\
\text { - } & \text { Slippery floors } \\
\text { - } & \text { Noxious fumes } \\
\text { - } & \text { Violence } \\
\text { - } & \text { Motor accidents } \\
\end{array}$ & $\begin{array}{l}\text { - Injuries caused by } \\
\text { machinery }\end{array}$ \\
\hline Financing industry & $\begin{array}{l}\text { - } \text { Fire hazard } \\
\text { - Steep stairs } \\
\text { - } \quad \text { Visual disturbances } \\
\text { - Electrical appliances/wiring } \\
\text { - Violence/robbery } \\
\text { - } \quad \text { Stress } \\
\text { - } \quad \text { Air conditioning -> upper } \\
\text { airway disease }\end{array}$ & $\begin{array}{ll}\text { - } & \text { Fire (buildings) } \\
\text { - } & \text { Bomb threats } \\
\text { - } & \text { Robbery } \\
\text { - } & \text { Illness }\end{array}$ \\
\hline Retail industry No. 1 & $\begin{array}{l}\text { - } \text { Back injuries } \\
\text { - } \text { Slippery floors } \\
\text { - Motor accidents } \\
\text { - } \quad \text { Air conditioning -> upper } \\
\text { airway disease } \\
\text { - Visual disturbances } \\
\text { - Violence/robbery } \\
\end{array}$ & - None mentioned \\
\hline Security industry & $\begin{array}{l}\text { - Violence } \\
\text { - Dog bites } \\
\text { - Back injuries } \\
\text { - Visual disturbances } \\
\text { - } \text { Motor accidents } \\
\end{array}$ & $\begin{array}{ll} & \text { Violence } \\
\text { - } & \text { Injuries/technicians }\end{array}$ \\
\hline Training centre & $\begin{array}{l}\text { - } \text { Motor accidents } \\
\text { - Defective machinery } \\
\text { - Violence/robbery } \\
\text { - } \text { back injuries } \\
\text { - } \text { Burns (stoves) }\end{array}$ & $\begin{array}{l}\text { - Defective machinery } \\
\text { - Motor accidents }\end{array}$ \\
\hline Industry No. 1 & $\begin{array}{lll}\text { - } & \text { Loss of hearing } & \\
\text { - } & \text { Inadequate } & \text { industrial } \\
& \text { house-keeping } & \\
- & \text { Motor accidents } & \\
\text { - } & \text { Back injuries } & \\
- & \text { Inadequate } \quad \text { protective } \\
& \text { clothing } & \\
- & \text { Dust } & \\
\end{array}$ & $\begin{array}{l}\text { - Loss of hearing } \\
\text { - Injuries on duty }\end{array}$ \\
\hline
\end{tabular}




\section{Ethical issues}

Ethical issues refer to those abstract codes and regulations that guide a researcher in conducting a study (Burns \& Grove, 1993:120). Respondents were informed in such a manner that they understood the procedure of the research and the research method. Written consent to participation was requested. Anonymity and confidentiality were assured as the names of the industries and respondents were not made known to the public. Privacy was assured by virtue of the fact that the respondents could complete the questionnaires at home without interference from outside.

\section{Data analysis}

The data was analysed in the computer centre of the University of the Free State on a Convex computer and SPPS programme (Statistical Package for the Social Sciences). Frequency tables and the Chi-quadrate analysis was performed by cross tables.

\section{Discussion of the findings Gender and age of managers}

Fourteen managers completed the questionnaire, 12 of whom were men and two women. Seven were between 25 and 35 years old, five between 36 and 45 years and only two fell in the age group 46 years and older.

\section{Occupational hazards in the specific industries}

The managers were requested to identify the occupational hazards in their industries. Table 3 indicates the managers' knowledge of occupational hazards in their industries. The researcher identified occupational hazards in the selected industries by means of the literature, the five star system of NOSA and observation of the working environment. As indicated in the table the researcher identified more occupational hazards. Only a

\section{Table 3: Managers' knowledge of occupational hazards in the industries $(N=14)$}

\begin{tabular}{|c|c|c|}
\hline TYPE OF INDUSTRY & $\begin{array}{l}\text { Occupational hazards } \\
\text { identified by researcher }\end{array}$ & $\begin{array}{l}\text { Occupational hazards } \\
\text { identified by managers }\end{array}$ \\
\hline Industry No. 2 & \begin{tabular}{ll|} 
& Defective machinery \\
- & Motor accidents \\
- & Inadequate industrial \\
& housekeeping \\
- & Back injuries \\
- & Violence/robbery \\
- & Visual disturbances \\
- & Noise \\
- & Dust \\
- & Inadequate protective \\
& Clothing
\end{tabular} & $\begin{array}{ll}\text { - } & \text { Machinery } \\
\text { - } & \text { Unsafe actions }\end{array}$ \\
\hline Retail industry No. 2 & \begin{tabular}{ll|}
- & Back injuries \\
- & Inadequate \\
& housekeeping \\
- & Motor accidents \\
- & Violence/robbery \\
- & Slippery floors \\
\end{tabular} & - Armed robbery \\
\hline Motor industry & \begin{tabular}{ll|}
- & Noise \\
- & Petrol fumes/fire \\
- & Visual disturbances \\
- & Slippery floors \\
- & Open gas appliances/ex- \\
& plosions \\
- & Back injuries \\
- & Inadequate industrial \\
& housekeeping \\
- & Motor accidents \\
- & Violence
\end{tabular} & - Defective machinery \\
\hline Hairdressing industry & $\begin{array}{ll}\text { - } & \text { Back injuries } \\
\text { - } & \text { Violence } \\
\text { - } & \text { Defective } \\
& \text { appliances } \\
\text { - } & \text { Slippery floors } \\
\text { - } & \text { Burns (boiling water) }\end{array}$ & $\begin{array}{l}\text { - Questionnaire not } \\
\text { received back }\end{array}$ \\
\hline
\end{tabular}


few of these were mentioned in each industry by the managers. As occupational hazards were not clearly mentioned in the responses

it may be interpreted as ignorance. It is cause for concern that occupational hazards such as loss of hearing and incorrect actions were not mentioned by some and that five managers could not identify any hazards.

\section{- Measures to protect workers from occupational hazards}

Table 4 indicates the measures that managers instituted to protect workers against occupational hazards. The managers could have indicated more than one measure:

Four of the managers left the question unanswered or indicated that occupational hazards did not apply in their industries. However, the researcher found that there were occupational hazards in all the industries (See Table 3).

\section{Need for occupational health services}

Eleven $(73 \%)$ of the managers felt a need for the identification of occupational hazards and advice about the prevention of injuries due to the indicated hazards. Ten $(66 \%)$ indicated that they also felt a need regarding the management of injuries on duty, first aid training and health education.

Nine $(60 \%)$ of the managers mentioned a need for the following services:

$\begin{array}{ll}- & \text { pre-employment examinations } \\ - & \text { periodic examinations } \\ - & \text { retirement examinations } \\ -\quad & \text { information regarding legislation } \\ -\quad & \text { information regarding safety programmes } \\ \text { - } & \text { information regarding occupational safety and hy } \\ & \text {-giene }\end{array}$

\section{Table 4: Addressing occupational hazards in an industry $(\mathrm{N}=14)$}

\begin{tabular}{|l|c|}
\hline MEASURES AGAINST OCCUPATIONAL HAZARDS & Frequency \\
\hline Supervision & 5 \\
\hline Action against workers who carry out dangerous actions & 2 \\
\hline Training the workers & 8 \\
\hline Providing protective clothing & 1 \\
\hline Not answered & 4 \\
\hline
\end{tabular}

Although five of the managers knew nothing about occupational hazards (see Table 3), it may be assumed from Table 4 that the training of workers is an important aspect of the prevention of occupational hazards, as eight of the managers indicated that they tried to prevent these hazards by training their workers.

\section{Statistics of injuries and illnesses}

The employers were asked whether they had statistics of injuries on duty and absence due to illness to determine the incidence. Twelve $(80 \%)$ of the industries did keep statistics of injuries on duty and absence due to illness. According to the statistics of the industries over a period of a year, seven managers indicated that there were fewer than $10 \%$, four that there were between 11 and $15 \%$ and only one that there were between 15 and $20 \%$ absences due to illness. This indicates that the industries surveyed in the research did not suffer serious

illness absences and injuries on duty.
The management of minor injuries was mentioned by $10(66 \%)$. It is clear that managers feel a need for occupational health services in their work places.

\section{- Occupational health services delivered in the industries}

Only one of the industries made use of a private occupational health nurse on an hourly basis. Two of the other industries receive visits from safety representatives of NOSA. The managers were asked why they do not employ an occupational health nurse. Six $(40 \%)$ replied that the industry could not afford one and four (26\%) did not answer the question. Two (13\%) felt that such a service was not necessary in a small industry. In response to the question whether they were aware of the health needs of the workers only four (26\%) answered yes. Eight (53\%) answered no and two (13\%) were unsure. 


\section{The employees}

Eighty-five employees returned the questionnaire which comprised an $80 \%$ response.

- $\quad$ Age distribution of employees considered when planning occupational health serv -ices and specific health education. The hazards of their posts and types of industry should be empha sized in education about occupational hazards,

\section{Table 5: Age distribution of employees $(N=85)$}

\begin{tabular}{|l|c|c|}
\hline AGE & Frequency & Percentage \\
\hline 19 years and younger & 1 & 1 \\
\hline $20-30$ years & 35 & 41 \\
\hline $31-40$ years & 27 & 32 \\
\hline $41-50$ years & 17 & 20 \\
\hline 51 years and older & 5 & 6 \\
\hline
\end{tabular}

According to Table 5 the greatest age distribution (73\%) was between 20 and 40 years. Only $1 \%$ of the workers were younger than 19 years, while $26 \%$ were older than 41 years. In total $93 \%$ of the workers were between 20 and 50 years old. These statistics show a normal distribution, because, according to Hurlock (1981:207) and Papalia (1995:365) early adulthood is from 18 years to 40 years and these are working people's most productive years when they are active in the labour market.

\section{- $\quad$ Language preference}

Most respondents (53\%) preferred Afrikaans and Sotho (27\%). Other languages spoken were English (9\%), Tswana (9\%) and Xhosa (2\%) as indicated in Figure 6.3. The main language groups in the industries are, therefore, Afrikaans and South Sotho. This corresponds with the language of the Free State region where most people speak these two languages.

\section{- Qualifications of workers}

The qualifications of the employees varied between Grade 7 and post-schooling training. The highest qualification of most of the workers ( $43 \%$ ) was Grade 12 (matriculation). Almost the same percentage of workers had Grade 10-11 (20\%) and post-schooling training (19\%) as their highest qualification. Only $18 \%$ of the employees had a lower qualification, that is, Grade 7 to 9 as their highest qualification.

\section{- $\quad$ Posts filled by employees}

The employees included in the research filled a wide spectrum of posts. These varied from $10(11 \%)$ ad ministrative posts, $14(16.4 \%)$ labourers, $10(11 \%)$ salesmen, $10(11 \%)$ supervisors, $32(37 \%)$ artisans and $3(3.5 \%)$ marketers. Two $(2.4 \%)$ each were mechan -ics, instructors, hairdressers, industry, switchboard operators and storemen. A book binder, chef, labora -tory assistant and teller were also included in the research. The posts occupied by the workers must be
Eighty percent of the respondents had at least two years' experience in the specific industry which could mean that they were aware of the occupational haz -ards of their posts. However, the $20 \%$ who had nought to one year's experience possibly could not yet iden -tify all the occupational hazards. Jeyaratnam (1992:128) emphasizes the responsibility of occupa -tional health nurses in pre-employment, periodic and retirement examinations and the follow-up of new workers in the industry, especially with regard to the identification of occupational hazards and the train -ing of workers to identify these hazards themselves.

\section{- Job satisfaction of the} employees

Workers were requested to indicate whether they were satisfied with their working circumstances. Seventytwo percent indicated that they were satisfied. Only $26 \%$ were sometimes unhappy in their work and two (2\%) were never happy in their work.

- $\quad$ Aspects that made workers happy in their work

Workers could indicate more than one aspect. Table 6 indicates that most of the employees $(50,6 \%)$ placed a high premium on good interpersonal relationships to ensure job satisfaction. An important factor for $24.7 \%$ was that their work should be challenging and recog -nition was important to $22.4 \%$, while $17.6 \%$ wanted to achieve good results. Good communication be -tween workers and managers was important to $11.8 \%$ of the respondents. Less important aspects for job satisfaction were good working conditions $(9.4 \%)$ and fairness $(7.1 \%)$, while only $1.2 \%$ of the respond ents mentioned a stable industry as an aspect that made them happy. Two $(2.4 \%)$ respondents indicated that nothing in the industry made them happy. 
Herzberg's motivation/maintenance theory emphasizes the characteristics of the work and the working environment as important factors in influencing behaviour in the work situation. Actual satisfaction in the work comes from intrinsic motivation. No employer can provide intrinsic motivation, but the work situation can be structured to encourage intrinsic motivation. This is done by providing motivation factors, that is, opportunities for personal development and promotion, recognition of achievements, challenges and responsibility. Herzberg also writes that hygiene factors do not need to be

\section{Table 6: Aspects that made workers happy $(\mathrm{N}=85)$}

\begin{tabular}{|l|c|c|}
\hline ASPECTS & Frequency & Percentage \\
\hline Justness & 6 & 7.1 \\
\hline Good interpersonal relations & 43 & 50.6 \\
\hline Stable firm & 1 & 1.2 \\
\hline Challenging work & 21 & 24.7 \\
\hline Recognition & 19 & 22.4 \\
\hline Good results & 15 & 17.6 \\
\hline Good communication & 10 & 11.8 \\
\hline Good working conditions & 8 & 9.4 \\
\hline No important aspects & 2 & 2.4 \\
\hline
\end{tabular}

\section{Table 7: Occupational hazards identified by workers $(\mathrm{N}=85$}

\begin{tabular}{|l|c|c|}
\hline \multicolumn{1}{|c|}{ OCCUPATIONAL HAZARDS IDENTIFIED BY WORKERS } & FREQUENCY & PERCENTAGE \\
\hline Term unknown & 42 & $49.4 \%$ \\
\hline No occupational hazards & 3 & 3.5 \\
\hline Exhaust gases & 4 & 4.7 \\
\hline Noise & 1 & 1.2 \\
\hline Communicable diseases & 2 & 2.4 \\
\hline Violence & 13 & 15.3 \\
\hline Back injuries & 2 & 2.4 \\
\hline Defective machinery & 13 & 15.3 \\
\hline Dust & 2 & 2.4 \\
\hline Slippery working surfaces & 3 & 3.5 \\
\hline Fire hazard & 4 & 4.7 \\
\hline Stepladders & 1 & 1.2 \\
\hline Electricity & 3 & 3.5 \\
\hline Too little protective clothing & 5 & 5.9 \\
\hline Smoke & 1 & 1.2 \\
\hline
\end{tabular}


excellent to make workers happy in their work. Many workers are happy and satisfied in their work without earning large salaries or working in ideal circumstances (Herzberg, 1968:61). The research shows clearly that motivation factors are very important to workers. Schilling (1981:183) stated that periodic investigations and inspections should be carried out by the occupational health nurses in the working environment to ensure that the workers remain happy in their work and that they are suited to the posts they occupy.

\section{Occupational safety}

\section{Occupational hazards in industry}

The employees were requested to make a list of occu -pational hazards which in their view, could be associ -ated with their specific industry. Table 7 shows the hazards identified by the workers.

\section{Table 8:Health needs of employees $(\mathrm{N}=85)$}

\begin{tabular}{|l|c|}
\hline NEEDS OF EMPLOYEES & Frequency \\
\hline Health education & 45 \\
\hline Family planning & 20 \\
\hline Management of minor ailments & 35 \\
\hline Mangement of drug dependence & 41 \\
\hline Management of depression & 17 \\
\hline Education and treatment of sexually transmitted infections & 30 \\
\hline
\end{tabular}

\section{Table 9:Influence of occupational health services on employees $(N=85)$}

\begin{tabular}{|l|c|c|}
\hline INFLUENCE OF OCCUPATIONAL HEALTH SERVICES ON EMPLOYEES & Frequency & Percentage \\
\hline Increases production & 31 & 37 \\
\hline Promotes health & 55 & 65 \\
\hline Saves medical expenses & 48 & 57 \\
\hline Enhances loyalty & 34 & 40 \\
\hline
\end{tabular}

\section{Aspects that make the workers unhappy in their work}

The two most important aspects that made the work -ers unhappy in their work were poor interpersonal relationships (19\%) and poor communication (15.2\%). Poor working conditions and poor salaries were sited by seven workers $(8.9 \%)$ as the causes of job dissatis -faction. Factors that the respondents regarded as less important causes of job dissatisfaction were poor results and staff shortages $(6.3 \%)$. Double standards, poor management and poor fringe benefits $(5.1 \%)$ were also mentioned as contributory factors. Only three (3.8\%) workers identified autocratic management and intimidation as causative factors, while $2(2.5 \%)$ men -tioned poor facilities and unrealistic pressure as un desirable aspects that could lead to unhappiness.

The following occupational hazards were not identified by the respondents but were observed by the researcher with the aid of the evaluation instrument:

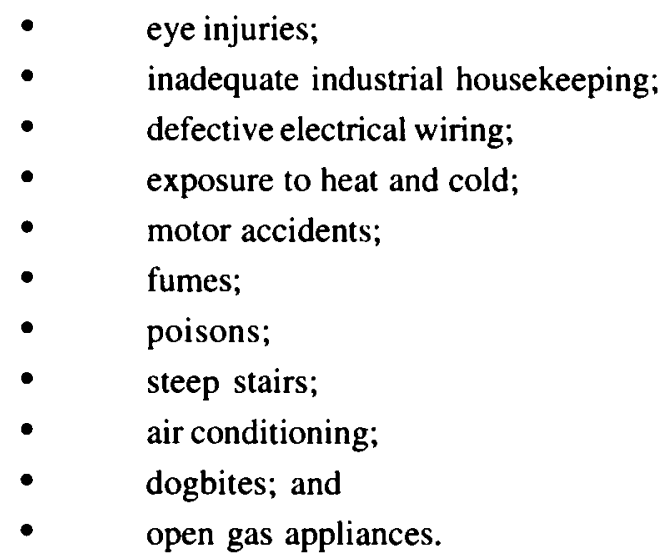


Although the employees identified more occupational hazards than the managers, it was significant that the term occupational safety was unknown to $49.4 \%$ of them. Three workers (3.5\%) were under the impression that there were no occupational hazards in their industry. The researcher investigated the working environment of all the industries in the sample and none were completely free of occupational hazards (see Table 3).

Table 7 indicates that five employees $(5.9 \%)$ identified a lack of protective clothing as an occupational hazard and four $(4.7 \%)$ identified exhaust gases. Three workers (3.9\%) sited slippery work surfaces and the use of electricity, two (2.4\%) communicable diseases, back injuries and dust, and one (1.2\%) worker mentioned noise, smoke and the use of stepladders as hazards.

According to this study $49 \%$ of male and $50 \%$ of female respondents were unaware of the occupational hazards in the industries in which they worked. Fifty-two percent of the South Sotho, Tswana and Xhosa-speaking respondents were not familiar with the hazards in their immediate working environment.

In the age group $31-50$ years $59 \%$ of the respondents indicated that they were unaware of the occupational hazards in their industries. This age group represented most of the workers (52\%) and they require health education regarding occupational hygiene. Kotze (1992:64) emphasized that the levels of exposure to specific stress factors must be within safe limits. Continuing supervision of the working environment and the workers by the occupational health nurse is necessary to ensure a safe workplace.

Fifty-five per cent of the respondents with low qualifications did not know about occupational hazards compared with $45 \%$ of those with matric and post-schooling training it may indicate that respondents with low qualifications are not aware of occupational hazards.

\section{Measures against occupational hazards}

\section{- $\quad$ Protective clothing and problems in the working environment}

Only $18(21 \%)$ of the workers were aware of measures instituted against occupational hazards by management but it was good to note that $72 \%$ of the employees were aware that protective clothing was to be worn. Fifteen (18\%) of the respondents believed that they became ill as a result of problems in the working environment.

\section{- Need for occupational health services}

The respondents were asked what their needs would be if an occupational health service were to be offered. Their needs are indicated in Table 8 . They were allowed to mention more than one need.

It appears from Table 8 that their greatest need was for health education (53\%). None of the respondents mentioned a safe working environment. According to Table 7 they did not know the term occupational safety and were therefore not fully orientated to occupational hazards.

Lastly the workers were asked how such a service, if it were instituted, would affect them with regard to their work. Their responses are shown in Table 9.

Table 9 shows that the respondents gave relevant responses, i.e. that production would be increased (37\%) and $65 \%$ mentioned the promotion of health. Again there was no mention of a safe environment or occupational hazards.

\section{Conclusions}

From the data obtained from employers it was clear that they were ignorant of occupational health and occupational hazards in their industries. It also appeared that they were not focused on these matters as only one manager mentioned protective clothing as a measure against hazards. However, they did indicate that they felt a need for services in their industries and that the most important reason for the lack of occupational health services was that they were unaffordable.

Although most of the workers were happy and satisfied in their work, they were ignorant of occupational hazards and safety aspects in their industries. The workers could identify more occupational hazards than the managers which indicates that management are not really focused on occupational safety. Workers indicated that they needed occupational health services with regard to health education and the management of minor ailments. They did not experience a need for a safe working environment. Sixty-five per cent of the workers mentioned that the institution of an occupational health service would promote their health, which was a relevant response and could indicate that they experienced a need for occupational health services.

\section{Recommendations}

- $\quad$ Occupational health nurses have an important task in providing information to employers and employees as this research showed that there is ignorance re garding occupational health.

Occupational health nurses should become visible and play their role in a manner that makes them really essential and indispensable.

Current occupational health legislation in the coun try should be enforceable

Gaps in the market, for instance the introduction of occupational health services to industries with more than 50 employees on an hourly and affordable basis by occupational health nurses should be taken up by nurses with initiative and drive. 


\section{Summary}

The objectives of this research were achieved, i.e. to identify the needs of management and workers for occupational health services. The most important reason, unaffordability, why these services do not exist in small and medium industries was identified.

Recommendations were made and it appears that the occupational health nurse is confronted with great challenges regarding the delivery of occupational health services and the visibility of her role in this essential speciality.

\section{References}

BUDWORTH, N 1997: The development and evaluation of a climate measure as a diagnostic tool in safety management. Institution of Occupational Safety and Health Journal, 1(1):1929.

BURNS, N \& GROVE, SK 1993: The practice of nursing research: Conduct, critique \& utilization. 2nd ed. Philadelphia: W.B.Saunders.

HERZBERG, F 1968: One more time: How do you motivate employees? Harvard Business Review, Jan.-Feb., 53-63.

HEALTH AND SAFETY EXECUTIVE 1997: Successful health and safety management, health and safety executive, HSG65. Sudbury UK: HSE Books.

HURLOCK, EB 1981: Developmental psychology. 5th ed. United States of America: McGraw-Hill Book Co.

JEYARATNAM, J 1992: Occupational health in developing countries. Oxford: Oxford University Press.

KOTZE, AJ 1992: Occupational health for the nurse and other health workers. $1^{\text {st }}$ ed. Kenwyn: Juta and Co.

LABUSCHAGE, W 2001: The importance of a systematic approach towards Occupational Health Noshcon 2001. Speaker's papers. Sun City.

MOUTON, J \& MARAIS, HC 1989: Metodologie van die geesteswetenskappe: Basiese begrippe. 3de uitg. Pretoria: J.C. Insto-Print.

PAPALIA, DE \& OLDS, SW 1995: Human development. 6th ed. New York: McGraw-Hill Book Co.

POLIT, D \& HUNGLER, B 1983: Nursing research. Principles and methods. 2nd ed. Philadelphia: J.B. Lippincott Co.

SCHILLING, RSF 1981: Occupational health practice. 2nd ed. London: Butterworths.

SCHOEMAN, W 1999: 'n Behoefte aan Beroepsgesondheidsdienste in Bloemfontein. Bloemfontein: Universiteit van die Vrystaat (M.Soc.Sc. Verhandeling).
SOUTH AFRICA (REPUBLIC) 1993: Occupational Health and Safety Act (Act 85 of 1993) Pretoria: Government Printer.

UYS HHM \& BASSON AA 1991: Navorsingsmetodologie in die Verpleegkunde. 2 de uitg. Pretoria: HAUM.

WILSON, HS 1989: Research in nursing. 2nd ed. AddisonWesley. 